\title{
Music and spatial injustice in banlieue cinema
}

Isabelle McNeill, University of Cambridge

[imm21@cam.ac.uk]

Trinity Hall, University of Cambridge

\begin{abstract}
This article examines the use of pre-existing music in French films set in impoverished banlieue neighbourhoods. It draws on Dikeç's (2007) concept of 'spatial injustice', which arises in a convergence of media representation and government policy, entrenching inequality, in the context of the 'fracture coloniale' in French society. Pre-existing music, with its wider spheres of signification beyond the film, potentially disrupts reifying visions of the banlieue. The article considers 'third space music' (Powrie 2018), applying the concept to contemporary cinema in the banlieue. For context, Le Thé au harem d'archimède (Charef 1985) and La Haine (Kassovitz 1995), show pre-millennial banlieue films using music as a shared cultural resource. La Haine begins to evoke a third space by foregrounding analogue 'sampling', a hip-hop practice in which dominant codes are appropriated and reconfigured, an aesthetics which Christopher (2019) argues has now pervaded contemporary digital life. Looking at pre-existing music in more recent films, Divines (Benyamina, 2016) and Swagger (Babinet, 2016), through the prism of 'third space music' and sampling, shows how these films use music in their search for alternative ways of representing the overdetermined space of the banlieue, whilst also confronting its spatial injustice.
\end{abstract}

\section{Keywords}

Film music; banlieue; urban space; French cinema; spatial injustice;

\section{Introduction}

In banlieue film, a contentious category of films centred on impoverished suburban areas and communities in France, music has often been used to express the frustrations of disenfranchised young people and to evoke feelings of empowerment and release. Whether in the angry call-to-arms of 2 Bal Niggets and Mystik's La Sédition during the riots at the end of Ma 6-T va crack-er (Jean-François Richet, 1997) or, more recently, the music video-like performance of Rihanna's Diamonds in Bande de filles (Céline Sciamma, 2014), cinema has foregrounded banlieue youths appropriating and responding to global music culture in powerful and moving ways. This article explores intersections, depicted cinematically, between the banlieue and music as a cultural object. I focus on the use of pre-existing music; it has an intertextual life beyond the film and as such a particular potential to interact with and shape the audiovisual representation of the banlieue as a social space. ${ }^{1}$ While there is a long history in cinema of appropriating pre-existing music rather than using a composed score (see e.g. Powrie and Stillwell, 2006), I am interested specifically in the potential of such music to exceed and reconfigure the culturally 
constructed space of the banlieue. Music is often chosen to respond to the ways in which banlieue identities and communities are situated within unequal power structures, which, as I will show, can be understood both in terms of a 'fracture coloniale' (Bancel et al., 2005) and through Dikeç's (2007) analyses of 'spatial injustice' in the banlieue.

Looking closely at the intertextual significations that open up through preexisting music illuminates how music creates a mediated space that goes beyond a segregating binary between periphery and centre. Powrie's conception of 'third space music' is useful in this context. My argument will examine in some detail his theorisation of ways of using pre-existing music which create a 'space of negotiation where different, alternative, subversive meanings emerge' $(2017,60)$. In the context of the banlieue, I will argue, third space music exposes tensions in French public discourse about these areas of urban space, disrupting habitual associations and representations. From a large corpus, I have chosen to refer to four films in which striking use of pre-existing music intersects with depictions of banlieue life. The first two films offer brief examples from a pre-millennial context. Analyses of sequences from Le Thé au harem d'archimède (Mehdi Charef, 1985) and La Haine (Matthieu Kassovitz, 1995), show different ways in which banlieue films have drawn upon popular music as a shared cultural resource, at a time still grounded in analogue culture. Both films tend to reproduce French universalist values, portraying the banlieue as a multi-cultural space where shared marginalisation is foregrounded rather than postcolonial fracturing. The ending of Le Thé au harem d'archimède provides an example of music use that remains in sync with and reinforces a cultural imaginary of the banlieue. It has what Powrie describes as a locating rather than a dislocating function $(2018,58)$. La Haine, however, begins to open up its location by introducing 'sampling' into its cinematic presentation of space, a hip-hop practice in which musical sources are appropriated and reconfigured. The widespread mainstream success of hip-hop has produced an aesthetics of sampling, which Christopher (2019) argues has come to define twenty-first century digital life. However, in La Haine sampling remains explicitly, indeed visibly, linked to its roots in analogue culture. In La Haine, the foregrounding of hip-hop refigures the banlieue as a porous, transnational space, thereby offering an alternative to the enclosed representations in dominant media representations. While La Haine therefore evokes some aspects of third space music, I will argue that its use of music nonetheless fits within expected narrative terms of reference; a more radical use of 'sampling' would destabilize such established codes.

The two more recent films I examine incorporate the borrowing and appropriation of sampling in the use of pre-existing music throughout their soundtracks, indeed opening up 'third space'. The fictional Divines (Houda Benyamina, 2016) and an unconventional documentary released the same year, Swagger (Olivier Babinet, 2016) both use music in unconventional ways, dislocating our viewing experience and evoking alternative possibilities in the banlieue. Sacred classical music (Divines) and 1950s jazz and rockabilly (Swagger), for example, are used at significant, affective moments. My reading of this in terms of 'sampling' will understand these films in a contemporary, digital soundscape in which new kinds of networked intertextuality create the potential for alternative connections between sounds and images, and where, '[t]echnologically enabled cutting and pasting are 
now preeminent practices' (Christopher 2019, 26). Crucially, however, both Divines and Swagger appropriate musical sources in order to resist preconceptions of the banlieue.

Both films grew out of a pre-existing partnership between filmmaker and actors/subjects: the principal actors in Divines had come through 1000 visages (1000 faces) Benyamina's not-for-profit organisation, which aims to create pathways into the film industry for those from underprivileged backgrounds. In the case of Swagger, director Olivier Babinet spent four years working with children at a secondary school (the Collège Claude Debussy) in Aulnay-sous-Bois, a commune of Seine-Saint-Denis. The film emerged from the film projects and relationships he developed with the children. Both directors aimed to challenge stereotypes of the banlieue, with Benyamina stating that she wanted to show the banlieue as it really is (Galy-Ramounot 2016), while Babinet has described his aim to bring audiences into contact with the individual 'beneath the hoodie' (Ben Youssef 2018). Alongside this desire for authenticity however, both Benyamina and Babinet reject reportage-style realism in favour of creative invention. Both films use music as part of these attempts to find alternative ways of seeing and feeling what Wakeman $(2013,84)$ has described as the 'overdone, over-imagined, over-cinematized space' of the banlieue, whilst also confronting its spatial injustice.

\section{Spatial injustice, third space music and sampling aesthetics}

As many have pointed out, the banlieue has become almost as overdetermined as the touristic centre of Paris (Wakeman 2013, 84; Vincendeau 2018, 87) with which it is intertwined as an opposing pole (Vincendeau 2018, 97). Any filmmaking set in these particular suburban areas must contend with the fact that the term banlieue, 'no longer serves merely as a geographical reference or an administrative concept, but stands for alterity, insecurity and deprivation' (Dikeç 2007, 8). This negative image of the banlieue has been widely disseminated by the mass media (Hargreaves $1996,607)$ and has been embedded in French urban policy: 'Journalistic categories used to frame banlieues have been institutionalized by state policies' (Dikeç 2007, 10), thereby entrenching segregation and inequality. The banlieue is also haunted by a colonial history that media and state discourse has often obscured, a disavowal that testifies to the ongoing 'fracture coloniale' in France. As described by Blanchard et al in 2005, the 'fracture coloniale' refers to social tensions arising from France's persistent refusal to confront the ongoing impact of colonial history. Before the 1970s, at the outreaches of the city were the hostels and shanty towns which developed after WWII as derisory lodging for immigrants from the colonies who were brought over as cheap labour. The huge HLM housing blocks ${ }^{2}$ that now dominate an imaginary of the banlieue were built in the 1950s and 1960 s as social housing, but only later became available to immigrants, while white-collar workers moved on as soon as they could. The existence and image of the banlieue in its current form are bound up in colonial history and the exploitation and management of resources - here human resources - by the French state. ${ }^{3}$ As Carrie Tarr has noted, positioning this new social housing on the outskirts of the city, 'effectively recreated the colonial geographic model of a city composed of adjacent but mutually exclusive parts' $(2006,6)$. Following a study of so-called 'quartiers sensibles', or problem areas, outside Paris and Angoulème, conducted from 2002, Didier 
Lapeyronnie concluded that this quasi-colonial geographic model also replicates the social and psychological effects of colonialism, "par un véritable "système" d'institutionnalisation du racisme et de rapports coloniaux' ${ }^{4}(2005,210)^{\prime}$. MameFatou Niang's more recent study $(2019,12)$ shows how the reproduction of colonial relations between centre and banlieue continues today through an administrative system that is grounded in universalist discourse: 'L'association entre la banlieue contemporaine et les villes colonials ne tient pas uniquement à la forte proportion de populations issues d'anciennes colonies. De nombreux parallèles existent dans leur gestion administrative et dans les discours autour de ces espaces' ${ }^{5}$

The other side of such disempowerment is the perception of banlieue inhabitants as a threat to national identity, understood through the French Republican model of secular universalism and assimilationism. As a space associated with the 'otherness' of identities originating in immigration, the banlieue has come to be construed in public discourse as a danger for social integrity and security. The banlieue riots of October 2005, responding to the deaths of two youths, Zyed Benna and Bouna Traoré, fleeing a police identity check, were covered by the media in ways that obscured police racism, emphasising instead the supposed criminality and/or radicalisation of those involved in the riots (Harsin 2015). More recently, the terror attacks of January and November 2015, claimed by ISIL, intensified public fear of radicalisation of French youths. As Chong Bretillon $(2018,149)$ has shown, the negative image of the banlieue youth has shifted from unemployed migrants to radicalised Muslims and international terrorists. Yet key aspects of otherness and threat remain constant. Niang has traced the multiple ways in which the heterogeneous banlieue population has over the years been repeatedly supplanted by the image of a singular, male, menacing, Muslim youth: 'Une image fixe, celle d'un individu en rupture avec la société' $6(2019,70)$.

Such representations figure the banlieue as a homogenous space of menace and violence, rather than as being inhabited by diverse political subjects. As Dikeç argues, drawing on Jacques Rancière's spatial and aesthetic conception of politics, 'the status of banlieues as well-delimited spaces with negative connotations undermined the possibilities of opening up spaces of politics in such areas' (2007, 17). His argument is informed by Rancière's (2000) notion of 'le partage du sensible', in which regimes of representation determine what appear to be the 'facts' of a particular environment or situation: that which is visible and articulated, those whose voices can be meaningfully heard (Dikeç 2007, 20). Inhabitants of the banlieue are designated as marginalised and threatening others, rather than as political citizens. Dikeç's study demonstrates how the distribution of sensible evidence shifted over the course of the last two decades of the twentieth century along with the neoliberalisation of the French state: 'The production of new terms and the putting in place of sensible evidences such as statistics - however flawed re-configured a perceptual field around the banlieues, which increasingly associated them with violence and delinquency' $(2007,168)$. Subsequently, repression (as opposed to other types of state response) becomes 'legitimised'.

The examples in this essay illustrate different ways in which pre-existing music in banlieue cinema confronts spatial injustice. While music in banlieue cinema has often played a significant role in highlighting social inequality, it runs the risk of remaining within a predetermined image of banlieue environments. There are some 
moments, however, where a piece of music does not straightforwardly make sense within the 'perceptive field' of an environment. It may be incongruous, unexpected or in some way 'other', destabilising the legibility of the scene and opening up a 'third space' in which new perceptions and positions may be negotiated. Pre-existing music may act as a 'foreign body' that disrupts a straightforward synchrony between or assimilation of sound and image. When it functions in this way, it becomes what Powrie calls 'third space music', drawing on Bhabha's use of the term 'third space' as a politically radical way of understanding hybridity (Powrie 2017, 60). For Bhabha $(1994,56)$, hybridity is a defining feature of culture, even though the latter is also perpetually engaged in restablisation into unity, which is why mixed and multiple identity seems to threaten 'national identity': 'The political union of the nation consists in a continual displacement of the anxiety of its irredeemably plural modern space' $(1994,213)$. For Bhabha, 'third space' undoes unifying conceptions of community, opening up new cultural negotiations (Bhabha, in Rutherford 1990, 219). Powrie draws on the concept of third space to conceptualise music that disrupts the stability of film's portrayal of historical space in his analyses of music in French heritage cinema. He contrasts third space music with two major tendencies of heritage films: utopian openness, where music 'supports the visual track by its utopian connotations of "open" maternal landscapes', and dystopian enclosure, in which music works 'to narrow space and what space represents' (2017, 52-59). Third space music, on the other hand, offers a way of understanding music 'whose lines of flight fissure and fracture the utopia/dystopia binary, creating a nomadic, indeterminate and constantly fluctuating space' (65).

Clearly, I am using Powrie's concept in a different context. Unlike the historical settings of the heritage film, cinematic depictions of the banlieue tend to foreground their contemporaneity. Nevertheless, there are parallels between the heritage film and the banlieue film (which emerged at a similar time during the 1980s) in the way they both locate a place and time for the spectator. As Powrie says of the heritage film, it 'can be recognised by its attempt to place the audience in a specific historical period by [...] surface details' $(2017,48)$. In locating the spectator, both heritage and banlieue film draw on a cultural imaginary beyond the film as well as particular ideas of Frenchness. For Powrie, third space music unsettles the spectator's straightforward apprehension of the image and rigid ideas about historical narratives, which is why I argue that it can unsettle predetermined images of the banlieue. Third space music often dislocates the audience in time (for example in anachronous musical idioms) or space (through music from elsewhere). Such strategies create a space of 'negotiation' (Powrie 2017, 60), where 'something new and unrecognisable' (Bhabha, in Rutherford 1990, 211) might emerge. This offers the potential for reifying, restrictive preconceptions of the banlieve as troubled and transformed.

Powrie's theorisation of third space music draws on Foucault's heterotopia (Powrie 2019, 59), with its idea of locations that both evoke and perturb their own meaning and representation. Significantly for my argument, however, Powrie distinguishes between the 'real topological spaces' of heterotopia and third space music which is 'not topologically locatable' $(2017,59)$. Third space music, like Bhabha's cultural 'third space', takes us beyond physical environments and into a space 'poised liminally on the window-ledge' between image and music, diegesis and 
world (Powrie 2017, 61). In contemporary cinema, this liminal space expands to include the networked, digital space which we often inhabit alongside the physical world. This forms a crucial context for the post-millennial films studied here, where incongruous music choices lead outwards into a vast archive of Internet images, sounds and information. Drawing on Christopher's (2019) analysis of hip-hop aesthetics and temporality in the information age, I suggest that incorporating music from other times and places can be likened to the hip-hop practice of sampling. This is a resonant paradigm for thinking about contemporary banlieue film in the context of spatial injustice, since hip-hop is 'the dominant form of cultural expression in the banlieues' and 'an important site of identity negotiations for minority youth in France' (Bretillon 2018, 147). I will argue that Divines and Swagger reconfigure banlieue space not by using hip-hop music, however, but rather in their use of a form of sampling, appropriating music from the past and present much as hip-hop 'borrows and builds from anything available' (Christopher 2019, 39). Christopher argues that hip-hop has come to define contemporary aesthetic practice, with its 'patchwork of the past' $(2019,39)$ that uses 'old outputs as new inputs' $(50)$. While sampling has its roots in a material, analogue practice of 'crate digging' for unusual musical sources and manipulation of vinyl, Christopher argues that in our contemporary information age, sampling is embedded in digital culture, in which codes are infinitely recombined in a push and pull between vast commercial interests and hackers making their own use of dominant culture (45). This embedding of sampling in contemporary culture is what I term 'sampling aesthetics'; it goes beyond the literal sampling in hip-hop records, into a wider phenomenon of 'against the grain' borrowing and re-use. I will argue that music drawn from other times and elsewhere in Divines and Swagger appropriates pre-existing forms to disrupt the codified space of the banlieue. Moreover, the interplay between dominant commercial systems and an outsider, 'hacker' activity is apt for the filmmakers of Divines (Benyamina) and Swagger (Babinet), who are both listed by Niang among filmmakers working on the margins of the French cinema scene, whose trajectories signal, 'le besoin de démocratiser un art aux codes hermétiques et d'élargir les sources de l'imaginaire national' $(2019,250) .{ }^{\underline{7}}$

\section{Music and the banlieue film: struggles for meaning}

The 'banlieue film' is a well-established term, recognised as a genre in the mid-1990s (Tarr 2005, 17). While the only definite common ground between banlieue films is their setting in the 'quartiers sensibles' of the banlieue, Tarr's study of 2005 described further areas of convergence: 'Foregrounding of the voices of the disadvantaged', an emphasis on 'the multi-ethnic nature of the French banlieue' and 'a combination of poetic realism and documentary approaches' (18). Bluher, on the other hand, associates the banlieue film with 'a mise-en-scène dominated by a violence and an aggression' that perpetuates stereotypes and 'results inevitably in an impasse' $(2001,85)$. Vincendeau $(2018,93)$ levels a similar criticism at the 'familiar banlieue tropes' of more recent films like Bande de filles and Divines, though Benyamina (in Galy-Ramounot 2016) rejects the labelling of Divines as a banlieue film, arguing that no-one calls stories set in the capital's centre 'Paris films'. In 2018, Reeck observed that 'banlieue film 'is still a problematic category,' (2018, 77), even as she observes the category's expansion, notably an increasing 
feminisation and the inclusion of comedy. Perhaps most crucial is Tarr's reminder that representations of the banlieue are 'discursive constructs and sites of a struggle for meaning' $(2005,18)$. This struggle for meaning takes place in the context of the spatial injustice evoked above, shaping and responding to it. Certainly, stereotypes of the 'quartiers sensibles' as marginalised and embattled are reductive, contributing to the reifying media imagery evoked above. However, simply ignoring the structural inequality embedded in some cités would also efface voices and lives which are under-represented or even erased by Republican disavowals of difference.

Music has been an important aspect of such 'struggles for meaning' in banlieue films, often reflecting the hybrid identities of the banlieue youths in the narrative. But such hybridity does not necessarily produce third space music. In some cases, pre-existing music has made palpable the struggle of spatial injustice but also risks fixing a particular image of the banlieue. For example, the music for one of the most well-known early films depicting banlieue life, Charef's Le Thé au harem d'archimède, was provided by Karim Kacel. Born to Algerian parents in Paris, Kacel's songs were inspired by 'la chanson française'. He aspired to be recognised first and foremost as a French singer in that tradition, rather than the 'porte-parole d'une communauté' $^{8}$ (Miliani 1995: 25). His breakthrough hit, Banlieue (1982), taken up in Charef's film, emphasised in its lyrics the marginalisation of banlieue youth and the limiting, suffocating horizons of the banlieue itself, evoking its 'horizon de tours' and 'grisaille' ${ }^{9}$ that provoke a craving for more expansive possibilities of existence. Yet both the musical setting and the lyrics avoid overtly invoking immigrant or ethnic experience, focusing instead on the banlieue as 'an environmentally determined space of illicit activities' (Derderian 2004, 150). Even if the melody that opens the song faintly evokes traditional Algerian music, the melody and guitar accompaniment escape clear cultural marking. As it appears at the end of Le The au harem d'archimède, this popular song would have been familiar to a French audience, its presence here signalling the bleakness of life in the banlieue. Significantly, a wordless version of the song is used; the voice sings 'na, na, na' rather than lyrics, suggesting that the audience can fill in the blanks. The audience is called to participate in the meaning of the film's conclusion, drawing on a shared cultural memory of the song and appealing to traditions of Frenchness (chanson française) that integrate singers like Kacel with postcolonial identities.

This appeal to shared culture and knowledge resonates with the narrative ending of the film, in which Pat, a young white youth, abandons his flight from the police, opting to be arrested alongside his friend Madjid, whose parents are Algerian immigrants. The music here, in other words, is in harmony with the narrative in which, as Tarr argues, '[the lead characters'] inter-racial friendship - however problematic and limiting - is the only flicker of hope to emerge from an otherwise pessimistic narrative closure' $(2005,60)$. Rather than producing a third space, the song coheres with the film's evocation of a shared French identity that assimilates ethnic differences. The struggle implicit in this appeal is for the acceptance and fair treatment of non-white French citizens with roots in postcolonial immigration. Yet ending with Kacel's song privileges the film's critique of the marginalisation of working-class youth in the banlieue over an interrogation of the 'fracture coloniale' in French society. As Vincendeau points out $(2000,321)$ this emphasis is a tendency that runs through 1980s beur cinema narratives. 
The famous 'black-blanc-beur' trio in La Haine (the black Hubert, white Jewish Vinz and Arab Saïd) also downplays ethnic difference. Unlike Charef, however, who grew up in the banlieue, Kassovitz approached the banlieue as a privileged outsider. Moreover, rather than focusing on intersections between French and diasporic identities, the film is saturated with the director's love of hip-hop and American popular culture. The film is infused with a hip-hop aesthetic that privileges sampling and remixing, as Higbee has shown $(2007,80)$, an argument expanded recently by Spence, who sees the film as structured by a hip-hop-like intertextuality (2018). There have been many critiques of the film's whiteness, its appropriation and commodification of black culture (as discussed in Vincendeau 2000, 323). Yet, as Sophia Maalsen has shown in her study of the agency and 'social life' of sounds themselves, sampling aesthetics resist the idea of creativity originating in a single author: the DJ or emcee's skill is in borrowing, recycling and mixing: 'Sampling critiques the idea of the auteur, originality, and the possessive individual' (2019, 137). This does not negate the problematic aspects of the film's production and reception but highlights the potential of sampled intertextual allusions to resist both homogeneity and postmodern superficiality: when seen in terms of hip-hop culture, allusions are not surface play but rather 'nodes around which communities organise their overlaps and interconnections' (Christopher 2019, 89).

I suggest that the sequence featuring Cut Killer's DJ performance foregrounds these ideas in the diegesis. The music traces multiple connections, across time as well as space. It begins before the performance, with Hubert in his bedroom listening to Isaac Hayes's rendition of 'That Loving Feeling' (1975). Hayes, a legendary soul singer, was also an anti-racism and black rights activist. His presence on the soundtrack connotes ideals of black resistance and success, resonating with the images of black athletes and boxers on the posters on Hubert's walls. 'That Loving Feeling' brings into Hubert's interior space a world outside the banlieue and beyond France, hinting at a pre-history of black American music. This prepares the way for the dense layering of samples that follow in Cut Killer's set, invoking a transnational community of suburban, diasporic subjects connected through global music culture.

We watch DJ Cut Killer from behind as he begins his set: the logo of Latino American rappers Cypress Hill on his T-Shirt adds to the layering of musical allusions (Figure 1). His musical mix is complex, with a beat from 'Juicy' (1994) by Notorious B.I.G., and samples - scratched and interwoven - from NTM's 'Nique la police' ('Fuck the Police', 1993), Assassin's 'Je Glisse' ('I'm Slipping', 1992), KRS One's 'Sound of Da Police' (1992) and, with playful incongruity, Edith Piaf's 'Non, Je ne regrette rien' ('No, I Regret Nothing', 1960). The beats and melody here are expertly blended by Cut Killer, but unlike in Kacel's song the different elements also retain a separate identity, connections to multiple sources. Chanson française, embodied by Piaf, is mixed in and made to resonate in what can be read, as Higbee does $(2007,83)$, as a postcolonial defiance of the violence of the French state. The emphasis on the DJ's virtuosic performance highlights the role of talent from the North African diaspora on an international stage: Cut Killer, aka Anouar Hajoui, was born in Morocco. Traditional French music is reappropriated as part of a transnational play of musical associations, challenging the enclosure of media discourse around banlieue space. 
INSERT FIGURE 1

Figure 1. DJ Cut Killer in La Haine (10 ${ }^{\text {th }}$ Anniversary Edition, Optimum Releasing 2004)

Visually, the Cut Killer sequence also traces a series of connections between different characters and spaces: it leads us from the interior of Hubert's bedroom, through the courtyard of the estate of La Noé, where La Haine was filmed, and into another room where DJ Cut Killer begins a set in front of a high window, huge speakers directing the sound out into the cite below. Finally, as the beats radiate out over the neighbourhood, the camera takes flight (by means of an early drone camera, or 'unmanned helicopter'), taking us over the banlieue rooftops and landing beside Vinz and Saïd. Sound and (aerial) vision become fused, as we appear to follow the trajectory of the music through the airwaves, an impression reinforced when Vinz and Saïd look up towards the sky and react approvingly to the Cut Killer mix. Sounds are nomadic here, they literally travel and fly, opening up different perspectives, evoking interconnecting cultures across borders.

The use of sampling in this sequence combines with the visual image of flight to evoke 'third space', unsettling the hegemonic image of banlieue youth, which is fixated on their status as 'marginal' to a French cultural 'centre'. However, the transnational hybridity suggested here is optimistically predicated on the idea of a 'post-racial', global youth culture of the inner city. This runs counter to the film's broader narrative of inevitable violence and catastrophe, but ultimately remains legible within preconceptions of banlieue space: we get the point even if we are outsiders to the community of practitioners and fans evoked in the skillful mixing of musical sources. Both Divines and Swagger, on the other hand, go beyond sampling as a specific hip-hop practice translated into cinema. These films can be viewed in the context of a broader, contemporary culture of media convergence and digitextuality, in which sampling aesthetics dominate cultural production. Incorporating pre-existing music in such a context creates a different kind of 'third space'. In both films, the music chosen already stands out as unusual, making us rethink our expectations of banlieue narratives. I will ultimately argue, however, that this incongruity - indeterminate in Divines, performative in Swagger - is amplified through contemporary viewing practices in which allusion leads us into a broader, networked space.

\section{The ambiguous sacred in Divines}

Released two years after Bande de filles made headlines with its four black female protagonists, Benyamina brought an alternative feminist perspective to the banlieue on screen from a Muslim woman of Moroccan heritage, claiming to show the banlieue 'as it really is' (Galy-Ramounot 2016). Having grown up in the banlieue, in the Erables neighbourhood of Viry-Châtillon, she found in filmmaking a way to channel the violent anger she felt at the injustice she witnessed growing up (Le Parisien, 2013). Divines was her first feature film, following several shorts, and was awarded the Camera d'Or at Cannes 2016. The 'divines' of the title are two feisty teenagers: Dounia, who lives with her mother in a Roma encampment on the edge of the cité (a marginal space within the margins), and her best friend Maimouna, who is black and a practising Muslim. The focus on these charismatic young women, 
along with their eventual boss Rebecca, a respected, uber-confident drug dealer, overturns the male-dominated image of the banlieue.

While some critics have observed deterministic clichés in the film's Bildungsroman narrative (Vogt 2017, 39), this is undercut, I suggest, by Benyamina's use of pre-existing music, which complicates sequences, investing them with an ambivalence that resists simplistic readings. The soundtrack is eclectic, a mixture of classical, electro, and edgy pop. The riff from androgynous singer Shamir Bailey's 'On The Regular' (2014) plays in the girls' imaginary car, in an exuberant sequence where fantasy overtakes a patch of concrete wasteland in the cité. Azealia Banks's 2011 'hit cunnilingus anthem' '212' (Simpson 2019) complicates the scene where Dounia performs seductively in a club for drug boss Reda. Dounia forms a relationship with a dancer, Djigui, and the scenes where she secretly watches his rehearsals from a hiding place in the rafters thematise questions of performance, self-expression and class (Djigui is presented as a working-class 'outsider' in the troupe). The scene where the two of them dance in an empty, after-hours supermarket is accompanied by Max Richter's 'Infra 8', a piece that defies genre and brings together opposites: classical strings and electronic processing, repetitive minimalism and searing emotion. This is a rich and complex soundtrack. I focus on one sequence that exemplifies the use of third space music in the film, at the moment when Dounia's big payoff finally comes.

Dounia has been tasked with seducing Reda and stealing his $€ 100,000$ stash; however, he becomes suspicious and brutally assaults her. She fights back and, with Reda incapacitated, possibly dead, searches the apartment for the money, bruised and bloodied from his attack. We hear the opening of 'Et In Terra Pax' from George Frederich Handel's Gloria (c.1706) as Dounia strikes the final blow to Reda's head and begins her search. When banknotes float down from a bathroom cabinet above her head, Dounia clasps the money in disbelief. As diegetic sound fades, we cut to an overhead shot of her in the bathtub, bathing in cash. 'Et In Terra Pax' is a measured, affecting piece of choral music for solo soprano accompanied by violins and continuo. The Latin text - 'et in terra pax hominibus bonae voluntatis' - proposes peace on earth to all men of good will. It is unexpected in this moment of hard-won payoff, ironic in its invocation of sacred glory as the dirty money rains down over Dounia's damaged face. The climax of the struggles over money and sexual power in the narrative feels at odds with the slow rhythm of Handel's music. It makes us alert to the hint of ambivalence in Dounia's reception of this gift from above, as she mutters 'mais non, mais non!'. ${ }^{10}$ Relief and exultation are palpable in actor Oulaya Amamra's performance, but the music primes us to worry about the significance of this moment.

There is (at least) one famous precedent for the use of baroque music in a narrative about drug deals and the criminal pursuit of money, also depicting the rise of an ambitious underdog. 'Tony's Theme' in Brian de Palma's remake of Scarface (1983) is an electronic adaptation by Giorgio Moroder of a passage from Henry Purcell's 1691 opera King Arthur. It functions as a melancholy motif in Scarface, underpinning the rise and fall of the film's charismatic and doomed protagonist, Tony Montana. As a motif it evolves in relation to Tony's narrative trajectory, always hinting at a tragic destiny. Such precedents mean that the use of baroque music in Divines is not completely alien. As in Scarface, the solemn pace and minor key of 'Et 
In Terra Pax' hint that no good will come of this exultant moment. Scarface is a pertinent antecedent since it is referenced from the outset of Divines. In a montage of smartphone videos, ostensibly filmed by the two young protagonists, Dounia declares, aping the French-dubbed version of Scarface, 'mes mains sont faites pour de l'or!'. ${ }^{11}$ As her hands finally do clasp Reda's 'gold', a further intertextual thread connects the two films through their music.

In Scarface, however, the piece is seamlessly integrated into Moroder's electronic score. In Divines, the appropriation of Handel's music as a separate element in its own right creates a more noticeable interference in the perceptual field of the scene. It is not only that its emotional textures sit uneasily with the scene, nor simply its anachrony as baroque music from the $18^{\text {th }}$ century. It is also a setting of a Christian text in Latin, in a film where the dominant religion in the narrative is Islam, making it a particularly resonant choice when we remember Niang's analysis of representations of the banlieue as homogenously (and fearfully) Muslim $(2019,54)$. The use of Christian music in Divines was an important feature of Benyamina's vision for the film. When asked about her use of sacred music, she explained that she wanted the sacred to be at the heart of the film, since she saw Dounia as someone battling her demons (Loria 2016). As Benyamina highlights in the same interview, the opening of the film also juxtaposes Muslim sacred music - a hadith chanted in the mosque - with music from a Christian tradition, Vivaldi's Nisi Dominus, in the next sequence. This interweaving of religions often presumed to be incompatible in French debates about 'identite nationale' runs through the film. The mosque is an integral part of the architecture of the cité, in which back corridors and ventilation shafts connect various spaces, allowing the girls to move easily between them. While a scene in a church is unmapped in relation to the cite space, it is connected to it through music - another deployment of Christian sacred music since Mozart's Requiem begins during previous scenes of Dounia and her family in the cité. The church is also linked to Dounia's banlieue life as the site of a drug transaction, where a shot-reverse-shot has Dounia recognise the icon of Christ as the same deity whom she asks, in whispered Arabic, for forgiveness. This juxtaposition is hinted at again in the payoff scene, where a large artwork suggestive of Islamic calligraphic art is visible in the background, framing Dounia as the banknotes tumble down from their compartment (Figure 2). Gesturing towards a common divinity transcending religious difference, such juxtapositions on the one hand align with Benyamina's aspiration to produce a 'humanist outcry' (Vogt 2017, 41). The most marginalised and precarious, Benyamina suggests, have an elevating spiritual existence beyond the materialism of everyday life.

\section{INSERT FIGURE 2}

Figure 2. Dounia discovers Reda's stash (Diaphana Édition Video 2017).

On the other hand, such a message is not straightforwardly expressed in the payoff scene. Here, Islamic art appears in a commodified form, as an ostentatious piece of décor in Reda's luxury bathroom. Looking closely at the artwork, it appears to be an interpretation of the tughras (royal insignia) of the Ottoman sultans. ${ }^{12}$ Arising from a tradition of Ottoman illuminations that were used to decorate both religious and non-religious texts, tughras are symbols of prestige and status rather 
than calligraphic inscriptions of Qur'anic texts. When understood as part of a set of signs to be displayed, the high art form of Handel's Gloria also seems codified, associated with bourgeois, European culture, a form of 'cultural capital'. Seen in this way, the music is less at odds with the image than initially apparent. The image and soundtrack propose different forms of capital, all of which are ultimately connected in capitalist systems, of which the material success of drug-dealers is the illegal flipside.

The effect of 'Et In Terra Pax' in the payoff scene is therefore indeterminate. Its mood and heterogeneous significations sit uneasily together in the way the music expands through and beyond the scene. A 'foreign body' is indeed introduced into diegetic space, destabilising us just at the moment when, in narrative terms, both the character and the audience of the film are given a moment of release. The audience enters a space of negotiation, the music creating a 'third space', in which assumptions of a straightforward and hierarchical separation between the banlieue as peripheral social space and a 'central' urban space of white, traditional French culture are called into question. Moreover, Benyamina's 'sampling' of different cultural sources and registers recalls a hip-hop aesthetic wherein codes are 'hacked', and 'appropriating the language of those in power is a significant act of resistance' (Christopher 2019, 27). As a woman of colour who has angrily described French cinema as a 'caste system' (Rose 2016), Benyamina's insistence on ambiguity in the juxtaposition of spirituality and materialism in her film indeed speaks of a resistance to reductive discourses about the banlieue. Her use of third space music reflects her resistance to categorisation and to the language (cinematic and verbal) of the French cultural elite: 'They couldn't say if my film was social-realist, popular cinema, arthouse [...] I don't want to speak this language [of the ruler]! I know how to speak it very well but I chose not to' (Rose 2016). While Divines largely rejects the hip-hop music that often dominates the scores of films set in the banlieue, its use of third space music nonetheless manifests an aesthetics of sampling, "hacking borders once inaccessible, circulating ideas into alien territories' (Christopher 2019, 89).

\section{Swaggering through space and time}

The idea of 'alien territories' is apt for thinking about media images of the banlieue, given the way in which spatial injustice functions in part through territorialisation, in which there is a presumed alienation between 'centre' and 'margin', the latter viewed as problematically 'other'. Third space music troubles such boundaries and binaries, refusing to respect representational codes. This is particularly powerful when combined with representations that expose blind spots in hegemonic discourse about the banlieue. Both Divines and Swagger foreground banlieue inhabitants' own critique of spatial injustice, with direct reference to architecture and environment. In Divines, it is Rebecca who points out the dilapidated high-rise buildings (shown in reverse shot) on which repair works have long since stalled. In Swagger, the documentary format gives voice to real school pupils of various ages, several of whom articulate their sense of spatial injustice with particular lucidity. Twelve-year-old Naïla Hanafi declares that she wants to be an architect, because architects from big cities have not understood banlieue life, designing buildings so tall that no-one wants to live in them. She tells a heartbreaking story of a child who fell from a high-rise balcony. The film goes beyond a characterisation of the banlieue 
as a site of working-class struggle and attests to the 'fracture coloniale'. Reiterating a point she has made in voice-off near the very start of the film over nocturnal drone images of the cité, Naïla observes that 'les français de souche' moved out of the cités when the Arabs and blacks moved in. She begins by describing those who moved out simply as 'les français' and has to correct herself, 'enfin, nous on est français, mais...', showing an understanding both that her community is French and also that it is segregated. ${ }^{13}$ Abou Fofana, a young man who considers his identity to be more rooted in the Ivory Coast than in France (though he has only visited Africa once), gives a careful account of colonial history and slavery, declaring that 'il faut pas oublier des choses graves comme ça'. ${ }^{14}$ The depiction of a multi-cultural banlieue in Swagger is therefore underpinned by reminders of the social divisions that stem from colonialism and postcolonial immigration.

Made by a white director 'of French stock', however, the film risks reproducing a narrative familiar from other school-based films such as Entre les murs/The Class (Laurent Cantet, 2006), which focus on a white teacher's struggles to encourage 'problem' children from immigrant backgrounds. Indeed, Babinet's presence as an auteur is felt in the film despite his absence from the screen. His signature delight in surreal incongruity and the reconfiguration of reality (as seen for example in the TV series he co-directed, Le Bidule, 1999-2000) is manifested in a scifi sequence imagining an alien invasion amidst the tower blocks, in vertiginous drone shots, and in artful editing that suggests reactions and communication between subjects whose interviews were clearly filmed separately. Yet the years of collaboration help to mitigate this: we feel the children to be authors too, since the film is shaped by their speech, arising from conversations led by the children themselves (Babinet, in Ben-Youssef 2018). Unscripted yet performed, their voices drive the film's aesthetic creativity. They explore their identities and ideas as they themselves become cinematic creations. This self-fashioning as cinematic subjects is reflected in the film's soundtrack, which shifts between numerous registers, suggesting diverse possibilities. The pre-existing music resonates with the children's words without ever being fully contained by them. The music is less ambiguous and distancing than the highbrow music used in Divines, yet it also opens up expansive and playful possibilities beyond the reifying clichés of the banlieue. More so than in Divines, its aesthetics evoke a digital culture with its accessible archive of music and images that can be infinitely recombined. The film even recycles shots from the music video for Life on Earth (Tomorrow's World, 2014), which Babinet previously made as part of his work in the school. Indeed, music video aesthetics are evoked in various sequences - such as Paul Turgot's dance, discussed below - through an emphasis on stylised performance and the kinetic energy of the mobile camera.

The music contributes to an implicit thread in the film questioning of the meaning of 'swagger', making us think about how the term is culturally articulated and embodied. Where the word once had a negative connotation, suggesting arrogance, through popular culture (especially hip hop) it has taken on a more positive meaning of cool, stylish confidence (Jones 2012). At the end of the film, however, an intertitle reminds us of the supposed first use of the term, in Shakespeare's A Midsummer Night's Dream (1595-1596), where the mischievous Puck scathingly wonders, 'what hempen homespuns have we swaggering here?', referring to the lowly 'mechanicals' who are getting above themselves by putting on 
a play for the Duke of Athens. It is unclear how we are to read the potentially disturbing connection here between the mechanicals - endearing yet inferior - and the young people performing themselves in the film. The invocation of Shakespeare reminds us that 'swagger' is, like the banlieue itself, the site of a struggle for meaning that depends on who speaks and what position they speak from. Two of the young people in particular, Paul and Régis, are accorded music video-like sequences that highlight their stylish swagger. To a soundtrack of third space music, they reconfigure the space of the banlieue as a site of cinematic possibility and play, growing out of their own developing sense of selfhood.

Paul David Turgot was born, he tells us, in Pondicherry in India. Like others in the film, his homelife is difficult. Moreover, he is seen as 'different', neither Arab nor black. One day, he explains, he decided to wear a suit and tie. He was mocked by many of his peers, but, encouraged by a group of girls, it became a daily habit. Towards the end of the film, Paul, in his suit, is filmed dancing nonchalantly through a low-rent shopping centre, holding a red umbrella and lip-synching to an unexpected music track: Jerry Arnold's 'When You Said Goodbye' (1957-1958), a lesser-known rockabilly song. While we later discover that Paul likes old-fashioned rock $\mathrm{n}$ roll music, retrospectively explaining the choice, the song offers none of the obvious symbolism of, for example, Hubert listening to Isaac Hayes. It works to jolt us away from assumptions in public discourse about the tastes, identity and clothing choices of young men from the banlieue. ${ }^{15}$ The Steadicam tracks backwards, following his movements and gliding smoothly through space (Figure 3). On either side of Paul are colourful displays (picking out the red of his umbrella), piles of crates, peeling paint, graffiti tags and, as he leaves the shopping centre, a woman using a shopping trolley as a brazier. The lack of wealth is obvious, but here the 'impoverished' space is transformed into a plural one of multiple possibilities, filled with the syncopated rhythm of the rockabilly bassline, Arnold's smooth voice, Paul's relaxed gestures. What the banlieue might produce, in terms of embodied identity, gesture and voice, is shown to be unpredictable, hybrid and resistant to knowledge by an outsider gaze. Once again, here, the music is from a different place and time. Although the song is rendered visually and rhythmically harmonious with the camera's fluid movement through the environment of a cité, it sounds strange, alien to prevailing images of the banlieue as a violent, threatening space. Similar to Dounia and Maimouna's Ferrari-driving sequence in Divines, the transformation of cité space into a fantasy world through music distils the ways in which Paul's inner life and exterior 'swagger' transcend the spatial injustice of the banlieue. The difficult reality of the cité is documented and visible in the frame but Paul is not contained by it. Instead we are witness to a 'third space' which fractures any homogeneous vision of the banlieue.

\section{INSERT FIGURE 3}

Figure 3. Paul dances through the cite (Rezo Films, 2017)

The first extended sequence focused on the flamboyant, fashion-obsessed Régis Marvin Merveille N'Kissi Moggzi further demonstrates the self-fashioning, through cinema, of the film's young subjects, in its interaction between music, urban space and self-presentation. Previously, in the opening scenes of the film, we have 
seen Régis in his bedroom at night, when a drone camera shot that has been roving over the heights of the cite enters through his open window high up in the tower block. The move from an elevated perspective over urban space to Régis's interior signals the power of the moving image to take us into interior worlds from which we may be detached in our everyday lives. As previously mentioned, it was Babinet's intention to counteract the spatially and emotionally distant media view of the banlieue environment, in which inhabitants of the cité are depicted as obscure, hooded figures (Ben Youssef 2018).

We return to Régis after Naïla's observations about banlieue architecture. Now the trajectory is reversed. We begin inside his room, with a shot of him looking in the mirror adjusting his bowtie (Figure 4). On the soundtrack, we hear the jazzy opening chords of Natasza Zylska's 'Ju-Bi-Ju-Ba' (1956). The camera pulls backwards and out of the window, as the sound of helicopter blades now joins the music track. This spectacular drone shot, which pulls back to reveal the whole block of high-rise housing, is reminiscent of the aerial shot in La Haine, which also moves out from high-rise domestic space into airspace above the cité, the sound of a helicopter blending with the music. This playful movement through space frames Régis as an individual who will not be contained within predetermined categories or trajectories. He is not the stereotypical angry young black man from the banlieue; neither is he a victim nor an outcast. Popular at school and an expert in the contemporary fashion industry, Régis's role model is the creative director of Balmain, Olivier Rousteng. He is not really straightening his bowtie in this scene; he is taking pleasure in his reflection. Régis knows he has 'swagger'. The pre-existing music here both enhances the portrayal of Régis's self-confidence and connects his enjoyment of style with an entirely different time and place.

\section{INSERT FIGURE 4}

Figure 4. Régis perfects his 'swagger' (Rezo Films, 2017)

A light-hearted song from one of Poland's most popular singers of the 1950s, 'Ju-Bi-Ju-Ba' conjures up old-school glamour, a fitting match for Régis' chic style, epitomised in his bowtie, as well as the poster of a huge diamond ring beside the mirror. The song's style feels familiar from movies of the same era (and similar styles reproduced in advertising), yet as a Polish song it is less likely to be specifically known by a French audience: it remains a 'foreign body'. The lyrics, which are not subtitled, riff about the song's own catchy tune and the nonsense sounds of the song's title refrain, as the singer complains she cannot stop singing it. ${ }^{16}$ The song's addictive jazzy qualities hold further significance when we reflect that in 1956 jazz was still officially condemned by the Polish communist state. In Swagger, set at a distance both from contemporary youth culture and from Frenchness, the song speaks of an ebullient pleasure in musical rebellion. Much as the camera is able to glide out of the room and into the air, the music transports us to another era and its different cultural tensions. That this sampling of music from the past playfully disrupts the discursive enclosure of the banlieue is further emphasised in the juxtaposition between two later sequences. The song accompanies Régis in front of a mirror once again, immediately after a Sci-Fi sequence imagining police surveillance 
drones filling the airspace of the cité. This dystopian image of banlieue life (emerging from the speculations of Naïla and Aîssatou) is punctured by the cut to the intimacy of domestic space where Régis grooms his eyebrows, the two shots linked by the date on his mirror clock: 2034. As he rebuffs his mother's attempts to hurry him from the other side of the door, we sense Régis's control over both his private space and his image, a far cry from the total surveillance evoked by the drones. At the same time, the strains of Ju-Bi-Ju-Ba resist the localisation of Régis within a stereotypical banlieue imagery, forming a space that is both protected and open. The 'third space' opened up by this music, then, is less through the creation of an unsettling incongruity as with Divines, and rather creates an expansion of the perceptive field of the banlieue into a space of multiple possibilities and alternative connections. Rather than destabilising the spectator with music that does not seem to fit the image, here it is the image, with its fluid camera movements in and out of domestic space that makes us listen closely to the music and wonder where it might lead. No longer an allusion aimed at a shared community as in La Haine, the music now leads to any space or time, sampled from an infinitely expanding archive and offering new nodes around which communities might form.

\section{Conclusion}

Comments beneath the YouTube videos of pre-existing music used in these films attest to the practice of following allusions outwards from the film, seeking the source. ' $X$ film brought me here' is a common formulation. Numerous comments under Hayes's 'That Loving Feeling' reference La Haine, while the user Leila Leila wonders who else was brought from Divines to the video of Richter's 'Infra 8'. More than one person has been drawn from Paul's performance in Swagger to online recordings of 'When You Said Goodbye'. While in 2006 Mike Cormack argued that, with pre-existing classical music on screen, 'the main part of the music's meaning in the film must, then, come from the music itself and how it interacts with the imagery' (22), this is increasingly less true, as viewing practices become more enmeshed with our networked daily lives, following flows of information, images and music from link to link. The third space music in Divines and Swagger points to a digital sphere of intertextuality, or 'digitextuality', that also encompasses a cinematic memory of banlieue and other films. In this context, we watch Divines and Swagger in relation to La Haine, not just in terms of a potential, uncertain cultural memory but through specific artefacts circulating online (one of the excerpts on YouTube of the Cut Killer sequence boasts 2.1 million views at the time of writing). Watching contemporary banlieue-set films in this context reveals their sampling aesthetics, foregrounded in analogue form in La Haine but now, as Christopher argues, a pervasive aspect of cultural production that unfolds into a networked, digital space of dissemination and reception. The ubiquitous digitextuality of contemporary life may have its own codes of containment (its echochambers and filter bubbles) but it also offers the potential for new pathways and the disruption of hierarchies and separation between 'peripheral' and 'central' space. Music can be a powerfully affective conduit for such spatial reformulations. In their creative sampling, Divines and Swagger channel the porosity of a global, networked culture in films that resist the rigid image of the banlieue that contributes to its continued marginalisation. The dynamism of the third space music in these films refuses to let expectations and 
interpretations settle, challenging us instead to hear the heterogeneous voices of the inhabitants of the cités.

\section{Contributor details}

Dr Isabelle McNeill is the Philomathia Fellow in French and Film at Trinity Hall, University of Cambridge, where she has taught film studies and French literature since 2005. She is the author of Memory and the Moving Image: French Film in the Digital Era (2010) and is completing a book on the rooftops of Paris in cinema. She is also undertaking preliminary research for a project on contemporary girlhood and making video essays.

\section{Disclosure statement}

No potential conflict of interest was reported by the author.

\section{Filmography}

Bande de filles, 2014, Céline Sciamma. France. Le Bidule, 1999-2000 (TV series, Canal+), Isabelle Ribotta, Didier Richarth, Olivier Babinet and Olivier Laneurie. France.

Divines, 2016, Houda Benyamina. France.

Entre les murs, 2006, Laurent Cantet. France.

La Haine, 1995, Mathieu Kassovitz. France.

Ma 6-T va crack-er, 1997, Jean-François Richet. France.

Mémoires d'immigrés, l'héritage maghrébin, 1997, Yamina Benguigui. France.

Scarface, 1983, Brian de Palma, USA.

Swagger, 2016, Olivier Babinet. France.

Le Thé au harem d'archimède, 1985, Mehdi Charef. France.

\section{References:}

Ben-Youssef, Fareed and Olivier Babinet. 2018. "Swagger: Interview with the Filmmaker." Dialogues (NYU Shanghai video series). https://www.youtube.com/watch?v=MB4BBZ2pG5M [accessed $8^{\text {th }}$ November 2019].

Bhabha, Homi. 1994. The Location of Culture. London: Routledge.

Blanchard, Pascal et al. 2005. La Fracture coloniale: La société française au prisme de I'héritage colonial. Paris: La Découverte.

Bluher, Dominique. 2001. "Hip-Hop Cinema in France." Camera Obscura 46: 77-97.

Bretillon, Chong. J. 2018. "'Double Discours': Critiques of Racism and Islamophobia in French Rap." In Postmigratory Cultures in Postcolonial France, edited by Kathryn Kleppinger and Laura Reeck, 147-165. Liverpool: Liverpool University Press.

Christopher, Roy. 2019. Dead Precedents: How Hip-hop Defines the Future. London: Repeater Books.

Cormack, Mike. 2006. "The Pleasures of Ambiguity: Using Classical Music in Film." In Changing Tunes: The Use of Pre-existing Music in Film, edited by Phil Powrie and Robyn Stillwell, 19-30. London: Ashgate.

Dikeç, Mustafa. 2007. Badlands of the Republic: Space, Politics, and Urban Policy. Oxford: Blackwell Publishing. 
Galy-Ramounot, Marion. 2016. “Houda Benyamina: J'ai montré la cité comme je la vois, pas comme elle est fantasmée." Madame Figaro, 31 August 2016, http://madame.lefigaro.fr/celebrites/divines-houda-benyamina-jai-montre-lacite-comme-je-la-vois-290816-116058 [accessed 8th November 2019]

Hargreaves, Alec. G. 1996. "A Deviant Construction: The French Media and the 'Banlieues'." New Community 22 (4): 607-618.

Hargreaves, Alec. G. 2013. "Banlieue Blues." In The Cambridge Companion to the Literature of Paris, edited by Anna-Louise Milne, 212-227. Cambridge: Cambridge University Press.

Harsin, Jason. 2015. "Cultural Racist Frames in TF1's French Banlieue Riots Coverage." French Politics, Culture \& Society 33 (3): 47-73.

Higbee, Will. 2007. Mathieu Kassovitz. Manchester: Manchester University Press. Jones, Charlie. 2012. "It's Official: Jay-Z Invented Swag." Dummy, 2 ${ }^{\text {nd }}$ April 2012. https://www.dummymag.com/news/it-s-official-jay-z-invented-swag/ [accessed $8^{\text {th }}$ November 2019].

Lapeyronnie, Didier. 2005. "La Banlieue comme théatre colonial, ou la fracture colonial dans les quartiers." In La Fracture coloniale: La société française au prisme de l'héritage colonial, edited by Pascal Blanchard, Nicolas Bancel and Sandrine Lemaire, 209-218. Paris: La Découverte.

Le Parisien. 2013. "Cinéma : les 1000 visages d'Uda Benyamina." $12^{\text {th }}$ January 2013. http://www.leparisien.fr/essonne-91/cinema-les-1000-visages-d-uda-benyamina12-01-2013-2473489.php [accessed 20th January 2020].

Loria, Sophie. 2016. "Divines (entretien)." http://esperluettesl.fr/conversation/divines-film-houda-benyamina/ [accessed 8th November 2019].

Maalsen, Sophia. 2019. The Social Life of Sound. London: Palgrave Macmillan.

Malausa, Vincent. 2014. "Bande de filles." Cahiers du cinéma 704: 46.

Niang, Mame-Fatou. 2019. Identités françaises: Banlieues, féminités et universalisme. Leiden and Boston: Brill Rodopi.

Miliani, Hadj. 1995. "Banlieues entre rap et raï." Hommes et Migrations (Musiques des Afriques: Voix Maghrébines et tempos blacks en Europe), 1191: 24-30.

Powrie, Phil. Music in Contemporary French Cinema: The Crystal-Song. London: Palgrave Macmillan.

Rancière, Jacques. 2000. Le Partage du sensible: Esthétique et politique. Paris: La Fabrique.

Reeck, Laura. 2018. "Gender and Genre in Banlieue Film, and the Guerilla Film Brooklyn." Romance Studies 36 (1-2): 76-90.

Rose, Steve. 2016. "Divines Director Houda Benyamina: 'It's Better to Make a Film Than a Bomb'." The Guardian, 10 ${ }^{\text {th }}$ November 2016.

https://www.theguardian.com/film/2016/nov/10/divines-director-houdabenyamina-its-better-to-make-a-film-than-a-bomb [accessed 8th November 2019].

Rutherford, Jonathan. 1990. "The Third Space: Interview with Homi Bhabha." In Identity: Community, Culture, Difference, edited by Jonathan Rutherford, 207221. London: Lawrence \& Wishart.

Spence, Steve. 2017. "Hip-hop Aesthetics and La Haine." Liquid Blackness 4 (7): 96115. 
Tarr, Carrie. 2005. Reframing Difference: Beur and Banlieue Filmmaking in France. Manchester: Manchester University Press.

Vincendeau, Ginette. 2018. "The Parisian Banlieue on Screen: So Close, Yet So Far." In Paris in the Cinema: Beyond the Flâneur, edited by Alastair Phillips and Ginette Vindendeau, 87-99. London: BFI Palgrave.

Vincendeau, Ginette. 2000. “Designs on the Banlieue: Mathieu Kassovitz's La Haine (1995)." In French Film: Texts and Contexts, $2^{\text {nd }}$ edn, edited by Susan Hayward and Ginette Vinceneau, 310-327. London and New York: Routledge.

Wakeman, Rosemary. 2013. "Independent Filmmakers and the Invention of the Paris Suburbs." French Politics, Culture \& Society 31 (1): 84-95.

\footnotetext{
${ }^{1}$ Hargreaves $(2013,212)$ helpfully summarises the specific meaning of the word banlieue that I will be using throughout this article: 'Although all of the urban spaces beyond the periphery of Paris intramuros are banlieues (surburbs) in the generic sense of the term, in recent decades popular usage of the word has been reconfigured and narrowed to denote certain types of highly stigmatised workingclass neighbourhoods, often referred to as cités'. For clarity, I will use 'banlieue' to refer to this stigmatised social space and 'cité' to refer to specific sites represented in the films.

${ }^{2}$ The term HLM, for habitation à loyer modéré, refers to the low-rent social housing blocks constructed in the 1960s under De Gaulle's presidency.

${ }^{3}$ I use these depersonalising terms intentionally as indicative of the attitude of the colonial apparatus: see Yamina Benguigui's film Mémoires d'immigrés, l'héritage maghrébin: Les Pères (1997), in which an official responsible for labour recruitment from the colonies refers to the men he brought over as 'product'.

4 'In a truly systemic institutionalisation of racism and colonial relations.'

5 'The link between the contemporary banlieue and colonial cities does not only stem from the large population of inhabitants from former colonies. Many parallels exist in their administrative management and in the discourses around these spaces.'

6 'A fixed image, of an individual disengaged from society'.

7 'the need to democratise an artform with hermetically sealed codes and to widen the sources of the national imaginary.'

8 'The spokesperson for a community'.

9 'Horizon of towers' and 'bleak greyness'.

10 'It can't be!'

11 'My hands were made for gold!' In the original English dialogue Tony says 'they oughta be picking gold from the street'.

12 I am grateful to Dr Deniz Turker for her expert analysis of the image.

13 'people of French stock', 'the French', 'well, we're French too, but...'

14 'One mustn't forget terrible things like that.'

${ }^{15}$ Niang illustrates how sportswear and a cap worn backwards have become a constant reference point in the media and even for politicians $(2019,70)$.

${ }^{16}$ I am grateful to Marta Rabreau for advice on the Polish lyrics.
} 